\section{THE RELATIONS OF MICROBES TO LIFE.}

OwING to the fact that some microscopic organisms have been shown to play an important part in many forms of disease, we are somewhat in the habit of looking upon such organisms in general as our enemies, forgetting many useful purposes which they serve. One of the most important processes taking place on the surface of the globe is the destruction of such organic masses as have been the seat of life, but which have suffered death. We have only to think for a moment what the result of a stopping of this destructive process would be, in order to gain a vivid impression in regard to its importance. The living thing can resist the destructive forces. When life ceases, the resisting-power is gone ; and, however complex the materials may be of which the organism is made up, they are quickly converted into simple and stable substances. The chief products of the changes are carbon dioxide, water and ammonia, all of which are of high importance, as from them again, under the influence of life, are elaborated the complex materials. Now, we know, that, in the breaking-down of organic matter after death, microscopic organisms play a principal rôle. They are the efficient scavengers of the earth. 'They effect the transfer of the oxygen of the air to the substances to be destroyed, and thus convert useless organic matter into that which is useful.

We thus see, that, while there are microbes which cause disease, there are others constantly at work keeping the conditions favorable to life. Recently the suggestion has been made, and by no less an authority than Pasteur, that the changes which are involved in the life-process of both plants and animals are probably intimately associated with the activity of what mas be called life-microbes. Pasteur read before the Academy of sciences a paper by Duclaux, in which some experiments upon the growth of plants in sterilized soils are described. Duclaux's paper begins thus: "The destruction of the organic matter of the soil by microbes, and the production of a new rege- tation on the soil, are two phenomena which always accompany one another. Is there any necessary connection between them? Through the labors of Pasteur, we know that microscopic beings can only live at the expense of complex materials elaborated by the plant with the aid of chlorophyl. Can the plant develop in the absence of microscopic beings? in other words, can it, without their aid, utilize the organic matter left by the plant which preceded it on the soil?",

With the object of attempting to answer this question, Duclaux experimented upon peas and beans. These were freed from germs, sown in a soil which was free from germs, and supplied with organic matter of a kind which one would naturally expect to be easily assimilated. The result was, that after one or two months the organic matter was found to be unchanged, and the plants did not thrive any better than when placed in distilled water.

Pasteur, in commenting on these experiments, takes occasion to suggest to Duclaux an experiment on the rôle which microbes play in animal life. The experiment is this. A hen's egg, from the surface of which all germs have been removed, is to be hatched in a sterilized space, fed with sterilized food, and supplied with sterilized air. Pasteur believes that the result will be that the chick will not live, and, in general, that life is impossible without the co-operation of microbes.

We must bear in mind that this is merely a suggestion, and that it rests at present upon no experimental evidence. Experiments of the kind suggested will involve great labor and the greatest accuracy. It cannot be denied, that, whether the results should prove favorable or unfavorable to the view of Pasteur, they would be of the highest interest to the chemist and biologist.

\section{THE CLIMATE OF THE EGYPTIAN $S U D A N$}

In so vast a region of country as the Egyptian Sudan, extending as it does over about sixteen or eighteen degrees of latitude and as many of longitude, with differences of alti- 
tude of more than six thousand feet on single parallels, it is evident that there must be great diversity of climate, a full discussion of which would occupy too much space for a reasonable article. But that portion of the Egyptian Sudan which at this time attracts the attention of the world by reason of the presence there of European troops, and the apparently intended operations of those troops, can be here concisely considered.

British troops now occupy two positions in the Egyptian Sudan; viz., the province of Dongola on the Nile, and the city and port of Suakin on the coast of the Red Sea

Italian troops occupy the port and vicinity of Massowah, on the Recl-Sea coast ; and the Bay of Assab and its vicinity, on the same coast, near the strait of Bab-ci-Mandeb.

Whatever may be the object of the Italian government in thus occupying positions on the Red-Sea coast, the object of the present British occupation is declared to be war against $\mathrm{El}$ Mahdi, and it will be necessary to consider the climate of the territories occupied by his forces.

El Mahdi now occupies and rules over the following : the province of Khartum, the province of Darfur, the vrovince of Kordofan, the province of Senaar, the province of Berber, the district of Gallabat, the province of 'Taka (excepting the capital, Kassala), and the great desert region between the Nile near Berber, and the Red-Sea coast near Suakin and Agig.

Thus we have to consider the climate in the provinces and districts above'named; and first the province of Dongola, now occupied by the expeditionary corps under Gen. Lord Wolseley, of prohably about nine thousand British troops.

'This is one of the rich and productive provinces of the Egyptian Sudan, extending from near Wady Halfa on the north, to the borders of the province of Berber along the course of the Nile. The correspondence from Lord Wolseley's corps has, during the past few months, made almost every hamlet and village throughout its length known to all parts of the world where newspaper's are read. The climate of the region now oceupied by the British force is not only good, but very agreeable, during four months of the year, - November, December, January, and February, - though February sometimes gives specimen days of the Khamseen wind which are very trying, even to natives of the country. During the months of March, April, May, and the first half of June, however, the climate, though not very unhealthy, is excoeding trying to all excepting natives of the country. The ordinary temperature is very high during the day; the thermometer in the shade often indicating from $95^{\circ}$ to $110^{\circ} \mathrm{F}$., while during the night the temperature falls to $65^{\circ}$ or $70^{\circ}$. This great difference makes it necessary to take great care to preserve health ; and, with the best of care, intermittent fevers are exceedingly prevalent. These, if neglected, are liable to take typhoid forms. During these months, the dust-storms coming from the southward are of most distressing frequency and violence. While these storms are hard to endure, and cause great suffering, I believe they to a certain extent destroy fever-germs, and prevent the climate from being so fatal to Europeans as it would otherwise be. From June to September the southerly and south-westerly winds come charged with moisture, though rarely yielding rain ; and, while relieved from the dust-storms, the European is more subject to fever influences.

Such is the climate in which the British troops are apparently to wait during the next five months, before advancing against their human enemy. Should they wait there, under the best possible care and with the best possible medical surveillance, the commander will be fortunate should the 'unseen enemy' not reduce his force by more than ten per cent before October next, while another ten per cent would be so debilitated by repeated fever-attacks as to require a month of cool weather to restore their strength, and make them fit for a vigorous campaign.

The climate of Suakin can hardly be considered unhealthy, but for the excessive heat which reigns there, except during the three months of December, January, and February. There the desert comes down to the very seabeach ; and the air of the desert, though burning hot, is not unwholesome. But the heat in that region, where sometimes during two or three successive year's rain does not fall, while the tropical sunbeams constantly bathe the rocks and sands, is of an intensity not to be conceived by those who have never experienced the like; and exposure to it by Europeans, without extraordinary precautions, is certain to produce sunstroke and congestions. The thermometer in April, in the shade, will often indicate a temperature of $100^{\circ}$ to $105^{\circ} \mathrm{F}$.; but even this does not indicate the effect upon a foot-soldier, who, marching in the sun, receives the direct rays, and, in addition, suffer's from the heat radiated and reflected from the lightcolorer? soil. It is, however, quite different with the mounted soldier, whether on horseback or on camel-back; as, if well covered, he 
suffer's less from the direct rays of the sun, and not at all from the reflected and radiated heat. As the entire route from Suakin to Berber is subject to heats fully equal to those of the vicinity of Suakin, it may be safely asserted that it is impracticable for European footsoldiers to make the march between those two points during the spring and summer months, except by using the night and early morning exclusively for marching.

The climate of the province of Berber is very similar to that of Dongola; but, owing to the effects of the waters of the river Atbara, in some parts of this province fevers are more prevalent during the summer months, and of a worse type than in Dongola.

In the province of Taka and the district of Gallabat, the climate from June to October is deadly for Europeans. During that season the rains are there copious, and, mingling with the floods of water coming down from the mountains of Abyssinia, cause the rich soil to become like a saturated sponge, while the rank vegetation and the exhalations from the soil render the air poisonous. From many districts the natives abandon the country in May, taking with them their families, their flocks and their herds, - to save themselves and their families from fever; and their flocks and herds from the ravages of the stinging insects which, during the season of rains, infest the country. These people go north to the deserts, and remain until the latter part of October, when they return, to find their own country delightful in climate, and glorious in vegetation. These conditions remain through the winter, and the air is healthful until April.

The climate of Khartum is hot, damp, and exceedingly unhealthy from April until October. The winter climate is not disagreeable; but even in winter the place can hardly be considered healthy, owing to the peculiar location of the town between the Blue and White Niles, and to lack of sanitary rule in the construction of the streets and houses. During the past twenty years, more care has been taken in the construction of dwellings; and the conditions are now more favorable than they formerly were.

The province of Kordofan is visited by less rain than that of Khartum or of Taka. During the winter, from the last of October until the 1st of March, the climate is very agreeable and quite healthy. The prevailing winds are from the north. The temperature is not high, ranging in the middle of the day from $80^{\circ}$ to $88^{\circ} \mathrm{F}$. The air is bracing and invigorating, while the nights are cool and pleasant.
March, April, and May are there the hottest and most disagreeable season, though not unhealthy. In June the season of rains commences, and it lasts until the latter part of September or early October. The winds are then from the south and south-west. 'The rains come in showers, sometimes daily, but oftener once in three or four days. The air is debilitating ; and fevers, intermittent in form, strike all excepting the natives.

No matter what care may be taken to guard troops from the effects of climate, the deathrate among soldiers is always great during this wet season. In an expedition which I sent into that province, well organized, well and very carefully commanded, well supplied, with good medical attendance and good hospital supplies, six per cent of the soldiers died during four months of the season of rains, while during the remainder of the year there were very few deaths.

The climate of Darfur closely resembles that of Kordofan. The rains come at the same time of year, and the sanitary effects of the different seasons are nearly the same; yet the fevers, according to the reports of the medical officers, seem to be more often severe in type in Darfur than in Kordofan. C. P. Stone.

\section{THE CAROLINE ISLAND ECLIPSE EX- PEDITION.}

The protracted duration of totality of the eclipse of May, 1883, early attracted the attention of astronomers; but an examination of its shadow-track on the earth showed the unfortunate fact that it would begin in the Pacific just east of Australia, and completely traverse the ocean, finally leaving the earth before the South American continent was reached. Only one eclipse had ever been observed with a greater duration of totality; and the possibility that an observing-station might be available in the small islands of the South Pacific determined Mr. Charles H. Rockwell of Tarrytown, N.Y., to endeavor to organize an observing expedition from the United States. Through his representations, the National academy of sciences was brought to consider the matter, and it was expected that Professor Young of Princeton would have the entire charge of the expedition. Unforeseen circumstances prevented this, and the party was finally organized with Professor Holden as chief, and sci-

Report of the eclipse expedition to Caroline Island, May, 1883. In vol. ii. of the Memoirs of the national academy of sciences. Washington, $1884.146 \mathrm{p}$., $22 \mathrm{pl}$. $4^{\circ}$. 